\title{
洋上風の乱れと波浪との同時生起性に関する 実証的検討 \\ STUDY ON OFFSHORE WIND CHARACTERISTICS IN JAPANESE COASTAL REGION BASED ON FIELD OBSERVATION DATA
}

\author{
永井紀彦 $1 \cdot 川$ 川浩二 2 ・吉村豊 $3 \cdot$ 吉岡健 4 \\ - 谷川亮一 5 - 青木功 6 \\ Toshihiko NAGAI, Koji KAWAGUCHI, Yutaka YOSHIMURA, Takeshi YOSHIOKA, \\ Ryoichi TANAKAWA and Isao AOKI
}

\author{
1フェロー 博 (工）（独法）港湾空港技術研究所 客員研究官（干239-0826横須賀市長瀬3-1-1） \\ 2正会員 博 (工）（独法）港湾空港技術研究所 海洋情報研究領域海象情報研究チームリーダ（同上） \\ 3非会員 工修 電源開発株 環境エネルギー事業部風力事業室長代理（テ 104-8165中央区銀座6-15-1） \\ 4正会員 工修 電源開発(株) 大間現地本部 大間原子力建設所 土木 $\mathrm{G}$ \\ （干039-4602青森県下北郡大間町大字奥戸字小奥戸281） \\ 5非会員 修 (環境科学) 伊藤忠テクノソリューションズ侏 科学システム事業部 \\ 新エネルギー・インフラ事業推進部新エネルギー課長（†100-6080千代田区霞が関3-2-5霞が関ビル） \\ 6 非会員 修 (環境科学) 伊藤忠テクノソリューションズ株) 同事業部同部 新エネルギー課（同上）
}

\begin{abstract}
Offshore wind farms have not yet been realized in Japan except for some plants near shore although they are desirable to promote the economy's sustainable growth with less $\mathrm{CO}_{2}$ emission. This paper introduces an example of a marine conditional study for offshore wind farm design, using NOWPHAS (Nationwide Ocean Wave information network for Ports and Harbors) data and newly developed numerical simulation system which is able to obtain meteorological and oceanographic phenomena at one time. The study aims to adapting the setting method of external condition in Japanese sea area to the design standard for offshore wind turbines of IEC 61400-3. Especially, statistical correlativity of the offshore waves and winds is important to estimate the external force acting on support structure.
\end{abstract}

Key Words : $\quad$ NOWPHAS, GPS Buoy, Wind Turbulence, Wave-Wind Joint Statistics, Wind Power

\section{1.はじめに}

広大なEEZを有する日本にとっては海洋エネル ギーの活用が重要であるが，これまで沿岸海域（特 に外洋）における風・波・流れなどの海象データは 十分とは言い難かった。したがって，洋上構造物の 設計条件に不確実性が大きく、洋上風力エネルギー のポテンシャルの把握が困難となり，その重要性は 認められつつも，海洋エネルギーの活用面で日本は 西欧諸国に遅れをとっているのが現状である.

本稿では，国土交通省港湾局関係機関の相互協力 によって開発・展開されたGPS 波浪計などの NOWPHAS（全国港湾海洋波浪情報網）海象観測の現 状を述心゙ ${ }^{1)}$, 洋上風力発電実用化に向けた NOWPHAS 海象観測情報の活用の検討事例を示す。すなわち， これまで観測データが少なかった洋上での風観測 データに注目し, 海洋構造物への外力条件として重
要となる洋上風の乱れ，および，海洋構造物の設計 条件設定の上で重要となる洋上風と波浪との同時生 起性 ${ }^{2)}$ についての，実証的検討結果を紹介する.

\section{2. 検討対象とした海象観測データ}

図-1にNOWPHAS観測網を示す。NOWPHASでは，海象 計に代表される海底設置式波浪計，および，GPS波 浪計によって，沖合および沿岸の波浪の常時連続観 測を実施している。また，GPS波浪計では洋上風の 観測も実施している ${ }^{3)-6)}$. これらの波浪観測機器に 加えて, NOWPHASでは沿岸潮位や沿岸域での風観測 も実施されている。NOWPHASの風観測は，沿岸域陸 上の港湾事務所等の近傍で実施されているものが多 いが，波浪観測拠点と一体的に洋上の観測塔・島・ 岩礁の上で洋上風を直接観測している観測点も存在 
している．ここでは，外洋沖合で波浪と洋上風を一 体的に観測しているGPS波浪計と, 洋上の観測塔・ 島・岩礁の上で洋上風を直接観測している観測点を 検討対象観測点として選んだ7),8). 表-1に、検討対 象とした波浪観測点の水深と風観測点の高さを示す. なお，GPS波浪計に取り付けられた風向風速計は， 海面高 $7 \mathrm{~m}$ である.

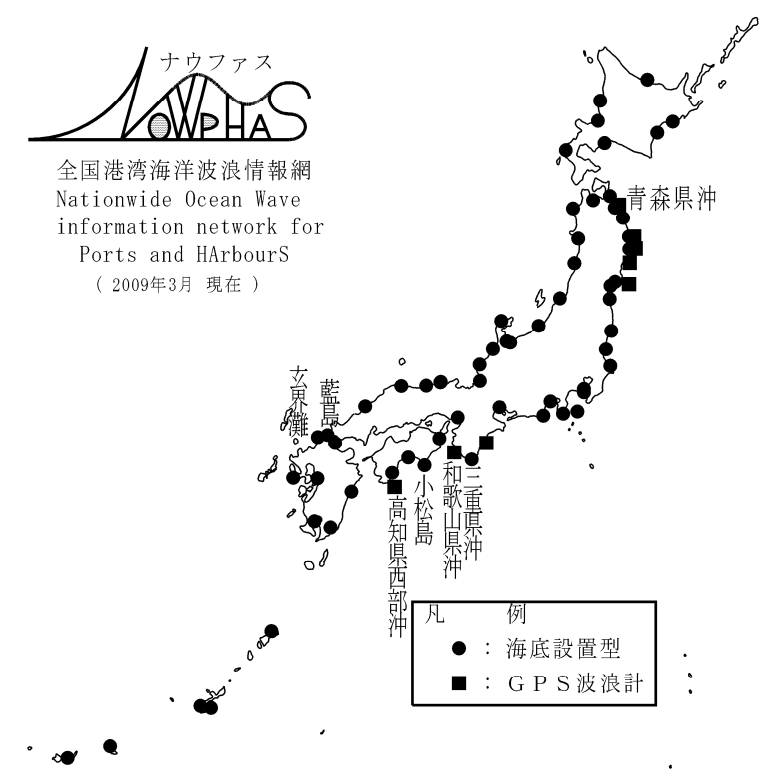

図-1 全国港湾海洋波浪情報網（NOWPHAS）

表-1 検討対象とした NOWPHAS 洋上風測地点の観測条件

\begin{tabular}{|c|c|c|c|c|c|}
\hline \multicolumn{4}{|c|}{ 固定点洋上風観測点 } & \multicolumn{2}{|c|}{ GPS波浪計 } \\
\hline 地点名 & 機種 & 標高 $(m)$ & 地上高 $(\mathrm{m})$ & 地点名 & 水深 $(\mathrm{m})$ \\
\hline 藍島 & 超音波 & 22.0 & 10.0 & 青森県東岸沖 & 87 \\
\hline 玄界灘 & 超音波 & 95.0 & 24.6 & 三重県沖 & 210 \\
\hline 小松島 & 風車型 & 0.0 & 15.4 & 和歌山県沖 & 201 \\
\hline & & & & 高知県西部沖 & 309 \\
\hline
\end{tabular}

\section{GPS波浪計による風観測記録の課題}

図-2は，GPS波浪計の上下摇と横摇の波浪応答特 性を示したものであるが，周期 $5 \mathrm{~s}$ 程度以下で共振に よる応答増加が顕著に見られることがわかる ${ }^{9)}$.
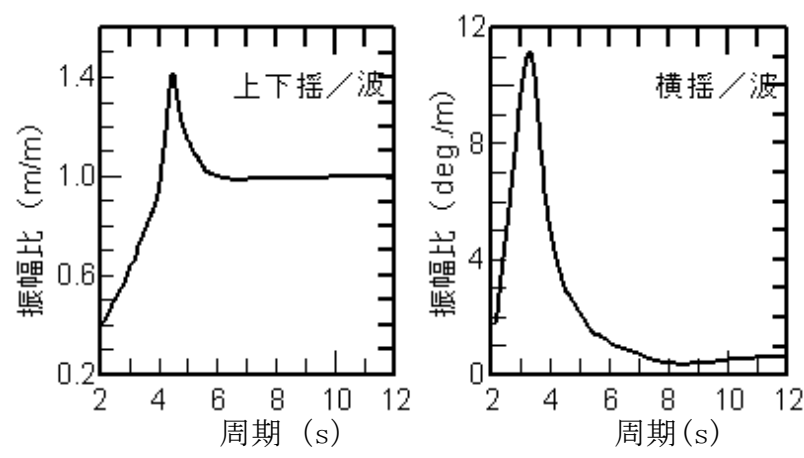

図-2 GPS波浪計の波浪応答特性

図-3は，ブイ動摇補正法の比較（単純差分補正と 5次ラグランジェの内挿公式適用の比較）を検討し
たものであり，周期 $4 \mathrm{~s}$ の規則的なブイ変位を仮定し たときの, 位相差および動摇振幅について, 単純差 分法および5次ラグランジェの内挿公式法を比較し たものである。ここに5次ラグランジェの内挿公式 法とは，式(1)の単純差分法で生ずる $\Delta t / 20$ 位相 差を避ける手法であり, 式(2)で示されるその点の 前後を含んだ5点の值からI時刻の微分值を求める手 法である ${ }^{10)}$ 。しかし，図からわかるように、たとえ 5次ラグランジェの内挿公式法を用いても、周期 $4 \mathrm{~s}$ の正弦動摇を1s間隔のデータサンプリングで変位計 測し速度を推定すると, 真值よりも変動振幅を過小 評価する。すなわち，GPS波浪計搭載の風向風速計 で得られる周期の短い風速変動については，1s間隔 の位置座標データを用いても，補正が困難である.

$$
\begin{gathered}
\left(d X_{i+0.5} / d t\right)=\left(X_{i+1}-X_{i}\right) / \Delta t \\
(d X / d t)_{i}=\left(X_{i-2}-8 X_{i-1}+8 X_{i+1}-X_{i+2}\right) /(12 \Delta t)
\end{gathered}
$$

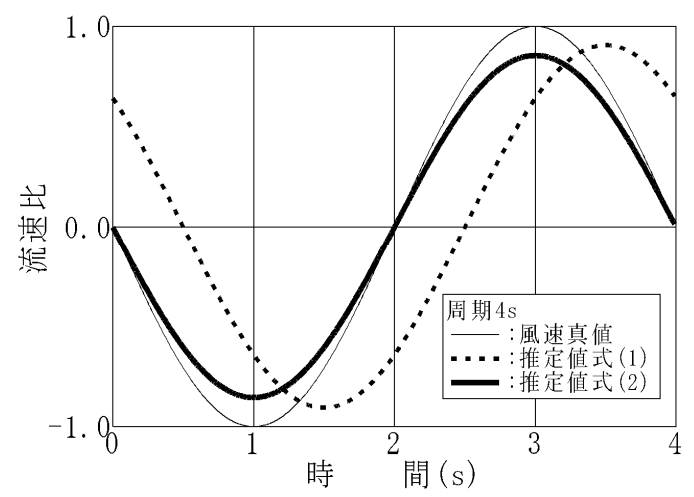

図-3 1sサンプルデータからの変動風速推定精度

さらに,GPS波浪計に搭載されている風向風速計 はプロペラ型であり，プロペラの慣性によってあま り周期の短い変動には風向風速計は追随できない問 題も忘れてはならない.

こうした, 洋上風の乱れの検討にあたってのGPS 波浪計の風観測の課題, 寸なわち, a) 上下摇と横摇 の固有周期に対応寸る周期 $5 \mathrm{~s}$ 以下のブイの動摇が大 きいこと，b)データサンプリング間隔が1sであるた め周期 4 s以下の短周期変動の観測が困難であること, c)プロペラ型の風向風速計であるため周期の短い風 変動に応答できないこと, などをふまえた工夫が必 要である。このため, 本稿では, 風観測波形記録を 再編集し周期10s以上の変動成分だけを抽出した. これよりも短周期の変動の定量的評価については, 超音波式固定点での洋上風観測が行われている観測 点のデータでそのエネルギー比率を評価し, 洋上風 の乱れ特性を評価した。 大水深洋上における波浪と 風との相関性は，有義波一10分間平均風速レベルと 個別波一ピーク3秒間平均風レベルとの，2段階でと りまとめた。相関性は, 波高と風速との回帰式を求 め, その相関の強さ (相関係数 $r$ ) 等のパラメータ で整理した。 


\section{4. 観測された洋上風の変動特性}

典型的な高波浪時における洋上風速の時間変動を 図-4に示す。高波浪時であってもうねり等の影響に より平均風速はさまざまである。風速の変動周期も 多様であることがわかるが，波周期よりは若干長め の周期 20-30s程度の変動が支配的となっているよう に見える．また，10分間の中で風速は変動するもの の，その変動幅は波高に比べれば小さく，10分間の 中で無風状態が生じたり，平均風速の2倍以上の瞬 間風速が生じたりずるような極端な風速変動は見ら れなかった。 なお，図-4に示す 4 事例は，後述する 表-2に対応する高波浪時の観測事例である.

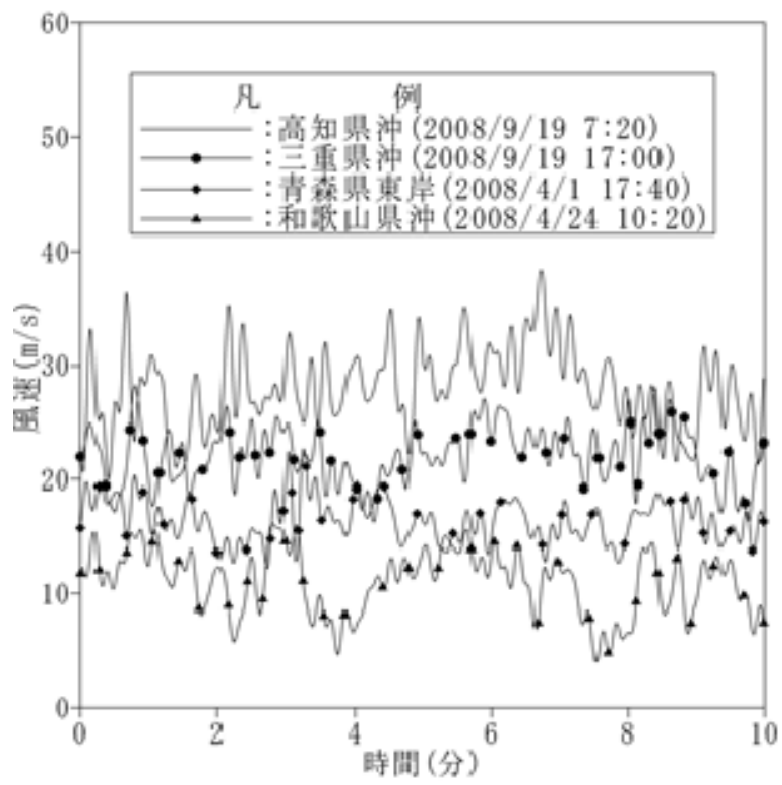

図-4 GPS波浪計による洋上風の変動解析例

洋上固定点で超音波式風向風速計による観測記録 のスペクトル解析の結果を図-5に示す。横軸は, 10 分間平均風速を示し，2008年を通じた各20分毎に取 得された10分間風観測結果毎にプロットを示してい る。プロットに対応する左縦軸は，各観測における 風速変動の標準偏差を示し, 太い直線は観測点毎の 標準偏差の平均值を意味している。また，右縦軸は， 風速変動の標準偏差を対応する平均風速で除した值, すなわち風の乱れ強度を意味しており，図中の太い 曲線は右縦軸に対応した，平均風速毎の風の乱れ強 度の平均值を示している。図から, 風速変動の標準 偏差は風速が大きいほど大きくなる弱い正の相関関 係が見られるのとともに，乱れ強度は風速によって あまり大きくは変動せず観測点毎にほぼ一定の平均 值を示している。すなわち, 洋上の観測塔上の小松 島で 0.1 程度, 離島観測点で若干の周辺地形の影響 を受ける立界灘と藍島で 0.2 程度の值であり，既往 の検討結果 $\left.{ }^{6)}, 7\right)$ とよく対応している.

図-6は，図-5に示す各観測毎に周波数スペクトル 解析を行い, 洋上に固定された風観測点における, 全風速変動の中の周期 $10 \mathrm{~s}$ 以上の長周期変動成分の 風速変動が占めるエネルギ一比を, 左縦軸に示した
ものである。また，プロットは2008年を通じた各20 分毎に取得された10分間風観測結果毎の值であり, 太直線はその平均值を意味している。なお，右縦軸 および太曲線は図-5と同じであるが，後述する図-7 との対比のため敢えて再掲した. いずれの洋上風固 定観測点でも, 変動成分の $95 \%$ 程度が周期 $10 \mathrm{~s}$ 以上 の長周期成分となっており，また，その割合は風速 階級によってもあまり変わらないことがわかる。

図-7は，図-6と同じ整理をGPS波浪計による風観 測記録に対して行ったものである.GPS波浪計は, 図-2で前述したとおり，横摇と上下摇の固有周期が 周期 $5 \mathrm{~s}$ 程度以下であるため, 結果として周期 $10 \mathrm{~s}$ 以 下の長周期変動成分の割合は洋上風固定観測点の図 -6よりも若干小さく，85-90\%程度となっている。 しかしながら，大部分の風速変動は周期 $10 \mathrm{~s}$ 以上の 長周期成分であることには変わりなく，風観測波形 記録を再編集し周期10s以上の変動成分だけを抽出 する整理法によっても，洋上風の乱れ強度を，ほぼ 正確に把握できることが明らかにされた。

図-7の右縦軸に対応する太曲線は，GPS波浪計に よって観測された洋上風の乱れ強度を風速の関数と して示した結果であるが，10分間平均風速が $5 \mathrm{~m} / \mathrm{s}$ を 超える条件では，乱れ強度は風速にはよらず， 0.12 程度のほぼ一定值を示していることが分かる。この ことは，GPS波浪計の風観測高度が海面上わずか $7 \mathrm{~m}$ であることを考えあわせると, 洋上風は陸上に比べ て非常に乱れ強度が小さい值となることを示唆して いるものである。

\section{5. 風と波の同時生起性の検討}

\section{（1）有義波を用いた検討}
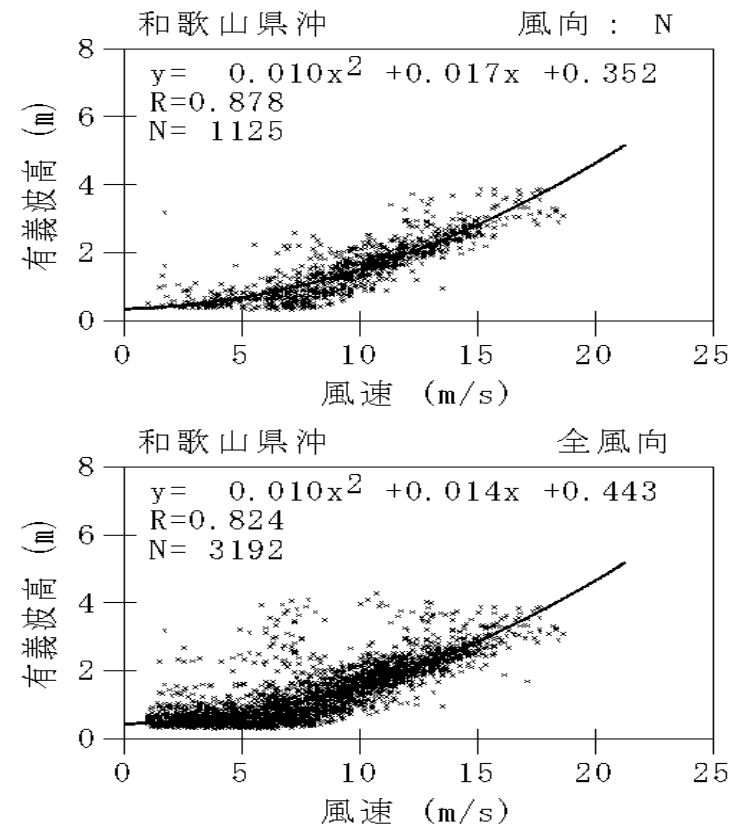

図-8 GPS波浪計による有義波高と平均風速相関解析例 

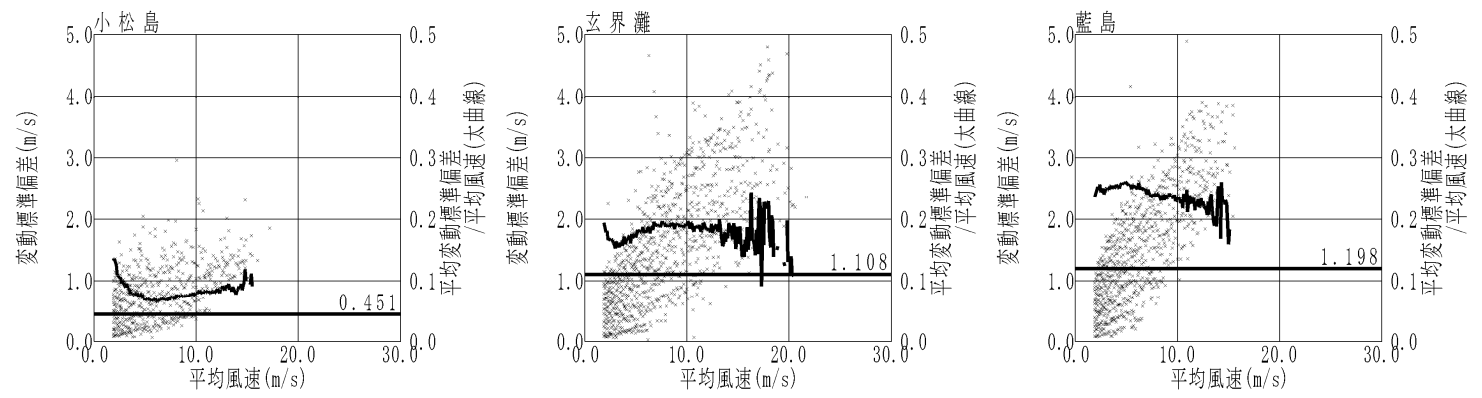

図-5 平均風速と風速変動量（洋上固定点）
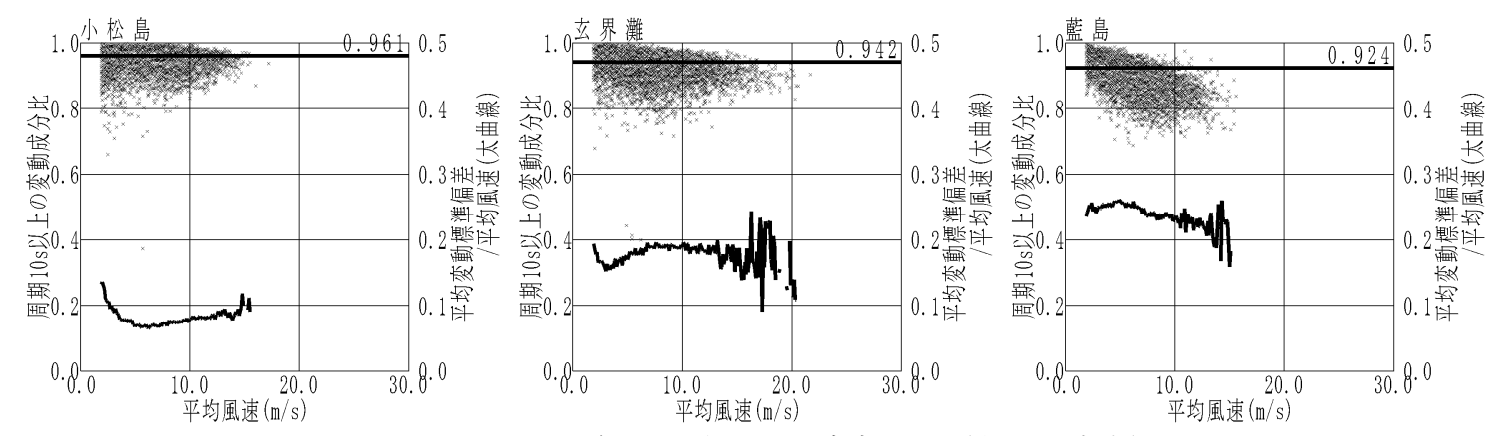

図-6 スペクトル解析に基づく風速変動比（洋上固定点）
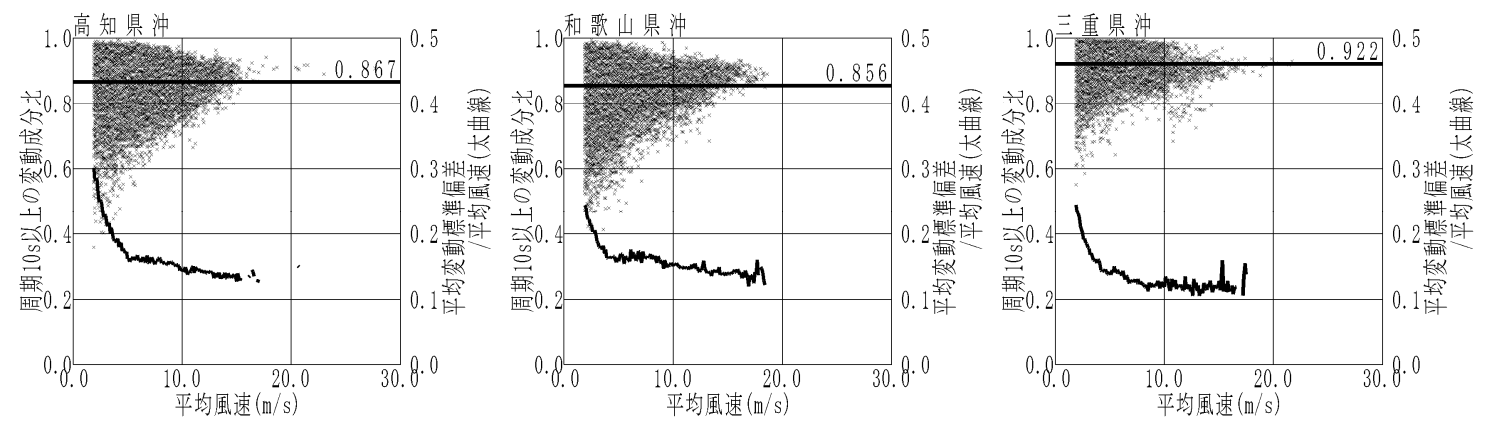

図-7 スペクトル解析に基づく風速変動比（GPS波浪計）

図-8は，有義波レベルでの波浪と平均風との相関 解析の結果の一例であり, 和歌山県沖における解析 結果を示したものである。上の図は北風の条件に絞 りとりまとめたものであり，下の図は全風向につい て整理したものである。波浪には，遠方海域より伝 播してくるうねり成分も含まれているため，風速と 波高は必ずしも1対1には対応しない。このため, 波 浪と風の相関を考察するためには，うねりと風波と を区分する何らかの条件付けが必要であるが，波向 き別の整理により相関性は向上寸ることが, 改めて 明らかにされた。

\section{（2）個別波を用いた検討}

表-2に，個別波を用いた波と瞬間風の関係検討対 象事例を，20分単位の観測時分とともに示寸.

図-9は，個別波レベルでの洋上風と波浪の相関解 析の一例であり, 表-2に示す高知県沖の強風時にお ける20分間における159波の個別波高と個別波中の ピーク $3 \mathrm{~s}$ 平均風速をプロットしたものである. 波郡 中の個別波高と瞬間風速との相関は極めて低く，ほ とんど無相関と言ってもよいことがわかる.

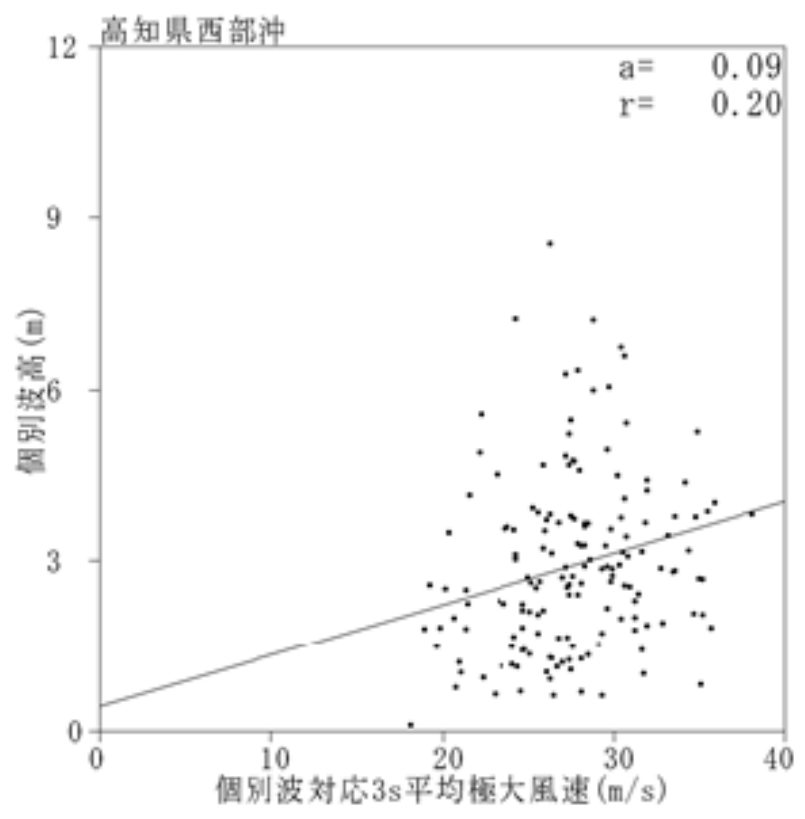

図-9 GPS波浪計による個別波高と瞬間風速の相関例 
高波浪時における他の観測事例でも, 個別波レベ ルでの波高と瞬間風速との相関性は, 図-9に示すよ うに $r=0.2$ 程度以下の極めて低い值であった。

図-10は，相関係数 $r か ゙$ 有義波高や平均風速によっ てどう変化するかを検討したものであり, 図-7で示 したGPS波浪計による観測データに関して，各年間 上位 500 観測の有義波高を記録した高波浪時におけ る，個別波高と，個別波中のピーク $3 \mathrm{~s}$ 平均風速およ び平均風速との, 各相関係数を示したものである. 縦軸に 20 分の観測から得られる有義波高を, 横軸に 当該 20 分間中の前半 10 分間の平均風速を示し，各観 測時点毎に凡例に示寸プロットの大きさで相関係数

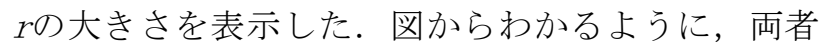
の相関関係が認められると考えられる なるプロットは極めて少なく，個別波高とその個別 波に対応する風速との相関性は極めて低いことが示 された，個別波に対応する代表風速としては，IEC 基準が定める3s 間平均極大風速 ${ }^{11}$ の他に, 当該個別 波周期中の平均風速に対する相関性の検討も下の図 で行ったが，相関性はさらに低いことが確認された。

このことは, 最大風速と最高波高が同時に生起す る可能性は極めて低く, IECの基準で定められてい るように洋上風車の支持構造物の設計においては, どちらか一方の荷重を低減することが可能であるこ
とを意味する ${ }^{11)}$ 。なお，瞬間風速と個別波高の出現 頻度分布（確率密度関数）は, 個別事例ごとには理 論的分布（波高はレーリー分布，風速は正規分 布）と若干異なる分布形状も見られたものの，平均 的に見れば，ともに理論的分布と実際の分布はよく 一致していた。 今後は，こうした知見を活かし，信 頼性理論に基づく同時生起確率により, 最適な風作 用と波作用の組合せ方法を検討する予定である.

\section{6. まとめと今後の課題}

以上, 現在のNOWPHASデータをもとに, 洋上風の 乱れと波浪との同時生起性についての検討を行い, 以下の結果を得ることができた。

(1)洋上風の乱れ強度として現れる時間変動は周期 10s以上の長周期変動成分のエネルギーが大部分を 占めるため, ブイの動摇特性, データサンプリング 間隔, 風速計の性質などによって短周期風速変動の 把握が困難であると考えられるGPS波浪計によって も，風観測記録を再編集し周期 $10 \mathrm{~s}$ 以上の変動成分 だけを抽出することによって, 洋上風の乱れ強度が 概ね適切に得ることができると考えられる.

表-2 GPS 波浪計による個別波高と対応瞬間風速との相関性検討例

\begin{tabular}{|l|c|c|c|c|c|c|c|r|r|}
\hline 地点名 & 年 月 日 時 分 & 波数 & $\mathrm{H} 1 / 3$ & $\mathrm{~T} 1 / 3$ & 波向 & 平均風速 & 風向 & 感度a & 相関係数 $r$ \\
\hline 高知県西部沖 & $2008 / 09 / 1907: 20$ & 159 & $4.62 \mathrm{~m}$ & $8.1 \mathrm{~s}$ & ---- & $28.0 \mathrm{~m} / \mathrm{s}$ & $\mathrm{NE}$ & 0.09 & 0.21 \\
\hline 三重県沖 & $2008 / 09 / 1917: 00$ & 177 & $4.17 \mathrm{~m}$ & $7.5 \mathrm{~s}$ & $\mathrm{ENE}$ & $22.1 \mathrm{~m} / \mathrm{s}$ & $\mathrm{NNE}$ & 0.12 & 0.19 \\
\hline 青森県東岸沖 & $2008 / 04 / 0117: 40$ & 137 & $6.02 \mathrm{~m}$ & $12.0 \mathrm{~s}$ & $\mathrm{ENE}$ & $16.5 \mathrm{~m} / \mathrm{s}$ & $\mathrm{NW}$ & 0.90 & 0.23 \\
\hline 和歌山県沖 & $2008 / 04 / 2410: 20$ & 169 & $4.28 \mathrm{~m}$ & $8.0 \mathrm{~s}$ & $\mathrm{~S}$ & $11.0 \mathrm{~m} / \mathrm{s}$ & $\mathrm{S}$ & 0.03 & 0.05 \\
\hline
\end{tabular}
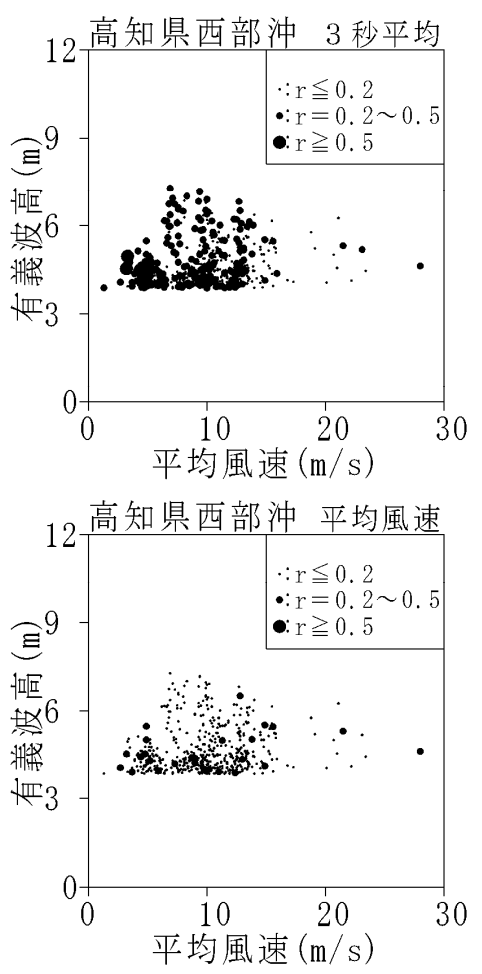
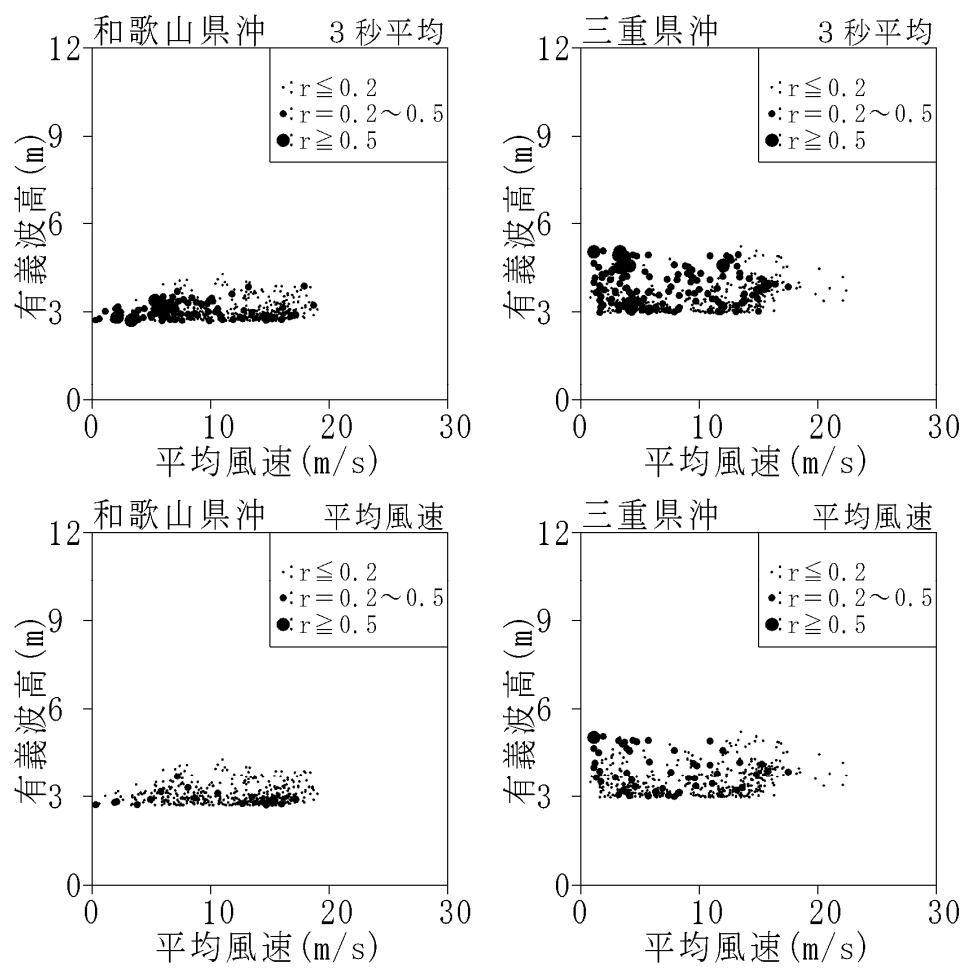

図-10 有義波高と平均風速に対応した相関係数 $r$ の值 


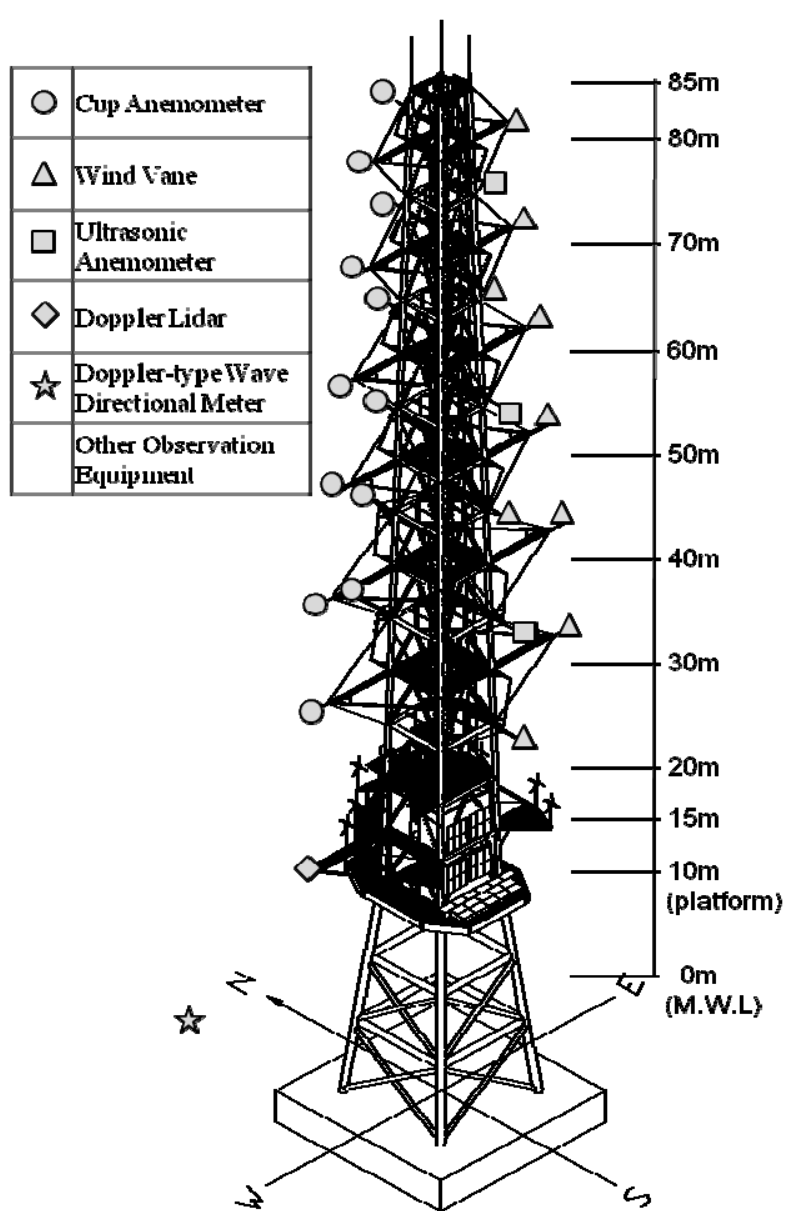

図-11 北九州沖に建設が予定されている洋上観測塔

(2)GPS波浪計によって観測された洋上風の乱れ強度 は，10分間平均風速が $5 \mathrm{~m} / \mathrm{s}$ を超える条件では，風速 にはよらず0.12程度のほぼ一定值を示した。このこ とは，GPS波浪計の風観測高度が海面上わずか $7 \mathrm{~m} ゙$ あることを考えあわせると, 洋上風は陸上に比べて 非常に乱れ強度が小さい值となることを示唆する.

(3)有義波レベルでの波浪と平均風との相関の考察に あたっては，う衫りと風波とを区分する何らかの条 件付けが必要であり，波向き別の整理によって相関 性が向上することが明らかにされた。

(4)個別波レベルでの波高と瞬間風速との相関性は極 めて低いことが確認され，IECの基準で定められて いるように洋上風車の支持構造物の設計においては, どちらか一方の荷重を低減する考え方が妥当なもの であることが確認された。

しかし，こうした知見は，GPS波浪計による海面 高度 $7 \mathrm{~m}$ という極めて低い観測点の風観測データに基 づくものであり，大型洋上風車のハブ高さとして想 定される海面上50-100mといった高度における風況 を必ずしも示すものではないことには留意が必要で ある.このため，現在，北九州港沖に図-11に示す ような海象計による波浪観測を伴う洋上風の鉛直分 布特性を明らかにするための洋上観測塔の建設が進
められつつある。こうした詳細な洋上風および波浪 の観測データに基づき，特に(4)については，信頼性 理論に基づく同時生起確率の検討を踏まえ, 最適な 風作用と波作用の組合せ方法を提案したいと考えて いる。

謝辞：本稿は，NOWPHASの波浪や洋上風の観測成果 に基づく研究成果であり，日頃からNOWPHAS観測網 の構築・運用・信頼性確保に従事されている国土交 通省港湾局関係機関の多数の方々のご尽力の上で, とりまとめることができたものである。また，本稿 は，新エネルギー・産業技術総合開発機構（NED0） からの委託による洋上風況観測システム実証研究 (北九州沖) 成果の一部を紹介するものでもある. さらに，本稿のとりまとめにあたっては，(株エコー の久高将信様および仲井圭二様のご助力をいただい た。これらの方々に，改めて謝意を表する.

\section{参考文献}

1) http://www. mlit. go.jp/kowan/nowphas/

2) 長尾毅・吉岡健：性能設計における相関を有する波 浪・風作用の組み合わせ方法に関寸る研究, 構造工学 論文集，Vol.56A，pp. 217-226，2010.

3) 永井紀彦 - 清水勝義 - 李在昫 - 藤田孝 - 久高将信 - 額 田恭史：ブイの動摇を考慮した GPS 波浪計による洋上 風観測, 海洋開発論文集, 第 23 巻, pp. 1003-1008, 2007.

4) 永井紀彦 ・清水勝義 - 佐々木誠 : 太平洋北東岸 GPS 波 浪計観測網が捉えた大水深域における海象特性, 港湾 空港技術研究所報告，第 47 巻 Vol. 2, pp. 1-52, 2008.

5) Nagai, T., Kawaguchi, K., Yoshimura, Y., Yoshioka, T., Tanikawa, R. and Aoki, I. : Study on Offshore Wind Turbines in Japan using NOWPHAS Data, Proc. Techno-Ocean 2010, CD-ROM

6) 永井紀彦・川口浩二・吉村豊・吉岡健 - 谷川亮一・青 木功: 日本沿岸の洋上風力発電立地に向けた NOW P $\mathrm{HA} \mathrm{S}$ 海象情報の活用, 海洋調査技術学会, 第 22 回 研究成果発表会講演要旨集, pp. 34-35, 2010.

7) 永井紀彦：風力エネルギー活用の観点から見た沿岸域 洋上風力の特性, 港湾空港技術研究所資料 No. 1034, 34 p. , 2002.

8) 永井紀彦 - 小川英明 - 中村篤 - 鈴木靖 - 額田恭史 : 観 測データに基づく沿岸域風力エネルギーの出現特性, 土木学会, 海岸工学論文集 第 50 巻, pp. 1306-1310, 2003.

9) 清水勝義 - 永井紀彦 - 里見茂 - 李在昫 - 久高将信 - 藤 田孝：ブイ動摇特性を考慮した大水深波浪観測データ 処理システムの構築, 土木学会, 海岸工学論文集 第 53 巻, pp. 1406-1410, 2006.

10）安田仁彦: 数值解析基礎, コロナ社, $208 \mathrm{p}, 2008$.

11) International Electro-technical Commission: "Wind turbines - Part 3, Design requirements for offshore wind turbines", IEC 61400-3, 128p., 2009. 